\title{
PÓS-GRADUAÇÃO E CAPES
}

\section{CAPES AND POS-GRADUATE}

Como militante e defensor da Pós-Graduação sensoestrito, constatamos, historicamente, que a Capes (Coordenação de Aperfeiçoamento de Pessoal do Ensino Superior) nos últimos anos fez uma reviravolta na sua orientação.

Se bem aprendi, agora, existem Programas e não Cursos para que não se misturem com a Especialização (profissional). No programa, as bases fundamentais se resumem em: prestígio à linha de pesquisa e, excepcionalmente, os projetos isolados; o pesquisador e o orientando são os sujeitos da ação; deve haver uma relação estreita entre os dois; a pesquisa clínica e experimental é o objeto indispensável à aprovação e à classificação dos programas e há necessidade de divulgar os resultados, mesmo antes da apresentação de tese para defesa, se possível for.

Melhor dizendo, vale mais uma pesquisa bem elaborada e publicada em periódicos de impacto do que uma discussão pública de monografias ou teses volumosas.

Nesse raciocínio impõe-se a exigência de outro capítulo, ou seja, o da Formação de Pessoal Qualificado.

A impressão que me fica, após discussões e palestras em reuniões científicas é de que não se está valorizando, especificamente, esse assunto como prioridade. No meu entender prepara-se o pesquisador no laboratório, mas há que qualificá-lo como docente e com formação humanística.

Vejo, então, uma carência na orientação da Capes no que tange à formação de pessoal docente e a necessária e indispensável formação humanistica. Não se cobra por isto. O que se ouve é linha de pesquisa, publicação de resultados e em revista de impacto.

Lamento muito sobre isso porque é mais consistente um humanista-pesquisador do que um pesquisador materialista.

Não sou eu quem pensa assim. Em "Introdución al Estudio de la Medicina Experimental”, 1944, Claude Bermard escreve (pag. 277):

"En la medicina humana nunca intervienen consideraciones de esta especie, porque la conservación de la vida del hombre deve ser el único objeto de la medicina. Pero, sin embargo, muchas veces el médico se ve obligado a tener en cuenta en su tratamiento, lo que se llama la influencia de lo moral sobre lo físico, y en consecuencia una multitud de consideraciones de familia o de posición social que no tienen nada que hacer com la ciência".

Em "Advice for a Young Investigator"; 2000, pág. 01, Santiago Ramón y Cajal reflete:

"O método único de reflexão favorecida pelos Pythagoreanos e seguidores de Platão (e seguidos nos tempos modernos por Descartes, Fichte, Krause, Hegel e mais recentemente por

\section{ECBC Alcino Lázaro da Silva} Professor Emérito da UFMG

\begin{abstract}
pelo menos parte de Bérgson) envolve exploração da mente ou da alma de alguém para descobrir leis universais e soluções para os grandes segredos da vida. Hoje esta aproximação pode somente gerar sentimentos de tristeza e compaixão, sendo a última devido ao talento perdido na perseguição de quimeras e o primeiro devido ao tempo e trabalho desperdiçados sem nenhum dó”.
\end{abstract}

Qual seria o ideal? Resume-se em duas rotas. Formar o pesquisador em linhas definidas e verticais, de onde muitas idéias serão geradas e, em segundo lugar, não menos importante, preparar pessoal docente humanizado no didático-pedagogia.

Comentar ou criticar não leva a nada. Sugerir é permitido:

Avaliação rígida de Programas é fundamental. Tem que ser, no entanto, na produção científica e na formação de pessoal docente humanizado. A produção científica deve ser de qualidade, contínua e desdobrada em seguidores. É a formação de recursos humanos. A avaliação do que se produz deve se referir à excelência da pesquisa (linha), à seriedade da revista e ao impacto que o trabalho produz. $\mathrm{O}$ impacto do trabalho (v.g. maior número de citações) deve ser mais importante que o impacto da revista. A Capes como Instituição idônea e necessária, nacional como é e de valor inconteste (houve uma tentativa de sua extinção que durou 48 horas, somente, no Governo Collor), precisa adquirir olhos de nacionalidade: valorizar o produto nacional; valorizar a pesquisa voltada para os nossos problemas, muitos "sui generis"; inverter a obrigatoriedade de publicação, ou seja, $1^{\circ}$ na nacional e $2^{\circ}$ na internacional e prestigiar a revista nacional internacionalizada. Para tanto, a Capes poderia criar ou adotar revistas nacionais que se tornassem internacionais pela qualidade e pela divulgação bilingüe. Em resumo valorizar o impacto da revista internacional, mas antes de tudo criar a nossa, nacional e com capacidade para ser respeitada em nível internacional. Fomento é um recurso que não lhe falta. Já temos condições de nos impor perante o público internacional. Está na hora de fazer com que nos leiam primeiro e depois nós os lermos, para uma unidade científica.

Mais nacional, mais patriótica, a servidão e o domínio cultural desaparecerão. Um país só se torna nação se se libertar da opressão cultural, mesmo havendo soberania econômica e cultural por parte dos alienígenas.

Os abnegados que exercem a arte e a ciência sabem, mas não se manifestam, que chegou a hora da virada. ACapes tem condições e competência para essa promoção. 